\title{
Üniversite Öğrencilerinin Yaşam Doyumu Üzerinde Etkisi Olan Sosyo-Demografik Etmenlerin Belirlenmesi: Tekirdağ Namık Kemal Üniversitesi Öğrencileri Üzerine Bir Uygulama*
}

\section{Analysis of the Socio-Demographic Factors on University Students' Life Satisfaction: Namik Kemal University Sample}

\author{
Elif Kıran ${ }^{\mathrm{a},{ }^{* *}}$, Şıvganur Kirman ${ }^{\mathrm{b}}$, Elif Baksı ${ }^{\mathrm{c}}$ \\ ${ }^{a}$ Dr. Öğr. Üyesi, Tekirdağ Namık Kemal Üniversitesi, Fen Edebiyat Fakültesi, Sosyoloji Bölümü, 59030, Tekirdağ/Türkiye. \\ ORCID: 0000-0002-8039-3822
}

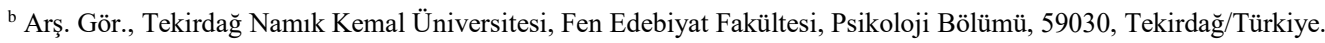
ORCID: 0000-0001-8125-3947

${ }^{c}$ Arş. Gör., Tekirdağ Namık Kemal Üniversitesi, Fen Edebiyat Fakültesi, Tarih Bölümü, 59030, Tekirdağ/Türkiye ORCID: 0000-0003-2680-4114

\section{MAKALE BILGİSI}

Makale Geçmişi:

Başvuru tarihi: 01 Eylül 2018

Düzeltme tarihi: 15 Eylül 2018

Kabul tarihi: 30 Eylül 2018

\section{Anahtar Kelimeler:}

Yaşam Doyumu

İş Kaygısı

Sosyal Çevre

Üniversite Öğrencisi

Beklenti

\section{ARTICLE INFO}

\section{Article history:}

Received 01 September 2018

Received in revised form 15 September 2018

Accepted 30 September 2018

\section{Keywords:}

Life Satisfaction

Employment Concern

Social Environment

University Students

Expectation

\section{ÖZ}

Bu çalışmanın amacı, üniversite öğrencilerinin genel yaşam doyumu düzeylerinin cinsiyet, kalınan yer, ekonomik durum, fakülte, iş kaygısı, sosyal çevre ve sosyal etkinlik değişkenlerine göre incelenmesidir. Araştırmanın örneklemi Tekirdağ Namık Kemal Üniversitesi'nde farklı fakülte ve bölümlerde öğrenim gören 775 öğrenciden oluşmaktadır. Öğrencilerden, Kişisel Bilgi Formu ve Yaşam Doyumu Ölçeği ile toplanılan verilerin analizlerinden elde edilen sonuçlar, üniversite öğrencilerinin yaşam doyumunun iş kaygısı, eğitim beklentisi, sosyal çevre, Tekirdağ'da yaşıyor olma, sosyal etkinliklere katılma sıklığı ve kalınan yer değişkenleriyle ilişkili olduğunu göstermektedir. Yaşam doyumunu yordamaya ilişkin ele alınan değişkenler toplam varyansın \%14'ünü açıklamaktadır. Bu bulgular doğrultusunda öğrencilerin yaşam doyumunu arttırmaya yönelik, sosyal etkinliklerin çoğaltılması, iş alternatifleriyle ilgili seminerlerin düzenlenmesi, psikolojik destek birimlerinin oluşturulması ve öğrencileri bilinçlendirme eğitimlerinin yapılması ile ilgili önerilerde bulunulmuştur.

\section{A B S T R ACT}

The aim of this study is to analyse general life satisfaction levels of university students depending on their place of accomodation, economic status, faculty, employment concern, social environment and social activity. The sample is 775 students from different faculties and vocational schools of Namık Kemal University which is a state university located in Tekirdag. Life Satisfaction Scale and Socio-Demographic Information Form was used for collecting data. The results have shown that the life satisfaction of Namık Kemal University students have a significance relation with employment concern, expectations related to education, social environment, living in Tekirdag, frequency of taking part in social activities and place of accomodation. The variables predicting life satisfaction explains $\% 14$ of the total variance. It can be concluded that organizing more social activities, organizing seminars related to job hunting, and building psychological consulting offices would be of help in contributing to the life satisfaction of university students.

\section{Giriş}

Bireyin yaşamını karakterize eden çoğu mücadelenin altında, mutluluk ve öznel iyi oluş kavramlarının yatıyor olması, psikoloji alanında son zamanlarda yapılan çalışmaların yönünün negatif ve hoş olmayan duygusal deneyimlerden genel pozitif duygulara ve psikolojik iyi oluşa çevrilmesine

\footnotetext{
*Bu çalışma, 20-21 Mayıs 2017 tarihlerinde İstanbul'da düzenlenen International Congress of Management Economy and Policy ICOMEP' 2017 isimli kongrede bildiri olarak sunulmuştur.

** Sorumlu yazar/Corresponding author.

e-posta: ekiran@nku.edu.tr
} 
neden olmuştur (Seligman ve Csikszentmihalyi, 2000). Üzerinde yoğun araştırmalar yapılan ve pozitif psikoloji olarak adlandırılan bu yeni alan pozitif olan öznel deneyimin ve bireysel özelliklerin yaşam kalitesini arttıracağı ve yaşamı anlamsız hale getiren patolojileri önleyeceği düşüncesi üzerinde durmaktadır (Seligman ve Csikszentmihalyi, 2000). Yaşam doyumu kavramı da öznel iyi oluş olgusunu oluşturan bireysel deneyimleri ifade etmektedir (Andrews ve Withey, 1976; akt. Diener, Suh, Lucas ve Smith, 1999). Pavot ve Diener (1993) yaşam doyumunu, bireylerin kendi öznel kriterlerini temel alarak, kendi yaşam döngülerinin beklentilerini ne ölçüde karşıladığını sorguladıkları, yani kendi yaşamlarının kalitesini değerlendirdikleri eleştirel bir süreç olarak tanımlamaktadır. Temelini duygular ve hislerden alan ve bireyin yaşamının zevke dayalı değerlendirmesini içeren duygulanım bileşenlerinden daha durağan olan yaşam doyumu, belirli bir zaman süresinden bağımsız olarak uzun süreli değerlendirmelerin yapılmasını mümkün k1lar (Eid ve Diener, 2004).

"Yaşam doyumu" faktörünün birey hayatındaki yerine yapılan vurgu gün geçtikçe artmaktadır. Buna paralel olarak, yaşam döngülerinin farklı dönemlerindeki yaşam doyumu düzeyleri, farklı meslek gruplarının yaşam doyum seviyeleri, yeryüzünün farklı coğrafyalarında yaşayan bireylerin yaşam doyum seviyeleri ve bu seviyeleri etkileyen parametreler gibi yaşam doyumunun çeşitli bileşenlerini içeren birçok çalışma yapılmaktadır. Üniversite yıllarının yetişkinliğe adım atılan ve bireylerin maddi ve duygusal anlamda o noktadan sonraki yaşamlarıyla ilgili önemli kararları verdikleri bir dönem olması nedeniyle bu yaş grubuyla yaşam doyumu üzerine yapılan çalışmalar da kritik bir öneme sahiptir. Bu kapsamda yapılan bir çalışmada üniversite öğrencilerinin yalnızlık düzeyi ile yaşam doyumu arasında ters orantılı bir ilişki olduğu bulgulanırken, ekonomik durum ve akademik başarı ile yaşam doyumu arasındaki ilişkiye bakıldığında bu iki faktörün yaşam doyumu ile doğru orantılı olduğu görülmüştür (Tuzgöl Dost, 2007). Benzer şekilde akademik başarı ve sosyo-ekonomik seviye ile yaşam doyumu arasındaki doğru orantı Kanada'nın Regina şehrinde okuyan lisans öğrencileri arasında da gösterilmiştir (Chew, 2003). Çivitçi’nin (2012) Pamukkale Üniversitesi öğrencileri üzerine yaptığı çalışmada ise, öğrencilerin yaşam doyumu oranı ile başarı ihtiyacı arasında doğru orantılı bir ilişki olduğu saptanmıştır. Tıp fakültesi öğrencileri üzerinde yapılan diğer bir çalışmada da sosyo-ekonomik düzeyi yüksek olan öğrencilerin yaşam doyumu ve özbakım gücünün yüksek olduğu sonucuna ulaşılmıştır (Ergin ve ark., 2011). Benzer şekilde Diener ve Diener (1996) gelir durumu ve sosyal statünün yaşam doyumuna etkisinin cinsiyetin etkisinden daha fazla olduğunu belirtmiştir. Çalışma sonuçları göz önünde bulundurulduğunda akademik başarı ve sosyoekonomik seviyenin yaşam doyumu ile olan ilişkisinin incelenmesi gerektiği gözler önüne serilmektedir.

Üniversite öğrencilerinin kaldıkları yere göre yaşam doyum oranlarının incelendiği bir çalışmada ise evde kalan öğrencilerin yurtta kalanlara göre yaşam doyumu oranlarının daha yüksek olduğu ve hem evde hem de yurtta kalan öğrencilerden ekonomik durumu iyi olanların yaşam doyumlarının daha yüksek olduğu görülmüştür (Özgür, Gümüş ve Durdu, 2010). Bu çalışmadan yola çıkılarak kalınan yer ile yaşam doyumu arasındaki ilişkinin önemi dikkat çekmektedir.
Yaşam doyumunu belirleyen bir diğer değişkenin ise algılanan sosyal destek olduğu düşünülmektedir. Delhi Üniversitesi'nde yapılan bir çalışmada yaşam doyumunun aile ve arkadaşlardan gelen sosyal destek ile doğru orantılı olarak arttığı sonucuna ulaşılmıştır (Mahanta ve Aggarwal, 2013). Ayrıca bilgi desteği, takdir edilme, motivasyon desteği ve duygularını açığa vurma desteğinin öğrencilerin yaşam doyumlarını üzerinde belirgin etkisi olan unsurlar olduğu da araştırma bulguları arasındadır. Türk ve Amerikalı öğrencilerin incelendiği diğer bir çalışmada ise yaşam doyumu düzeyini en belirgin şekilde etkileyen iki faktörün sosyal destek ve maddi özgürlük olduğu, uyum ve algılanan stresin yaşam doyumuna etkisi açısından ise bu iki grubun birbirinden farklılaşmadığı görülmüştür (Matheny, Curlette, Aysan, Herrington, Gfroerer, Thompson ve Hamarat, 2002).

Farklı fakülteler arasında yaşam doyumu oranları açısından anlamlı farklılık olup olmadığını Palacky Üniversitesi öğrencileri arasında araştıran bir diğer çalışmada ise en yüksek yaşam doyum skorlarının Spor Bilimleri Fakültesi öğrencilerine ait olduğu görülmüştür. Bireysel tatmin, özdeğerlendirme ve cinsel durum açısından da benzer sonuçlara ulaşılmıştır. Bu verilerden yola çıkarak bu öğrencilerin fiziksel aktivite ve algılanan yaşam doyumları arasında olumlu bir korelasyonun olduğu sonucuna varılmıştır (Sigmund, Kvintová, Hřebičková, Šafár, Sigmundová, 2014).

Yaşam doyumu üzerine cinsiyetin etkisini inceleyen çalışmalar çelişkili sonuçlar vermektedir. Örneğin, Tuzgöl Dost (2007) ve Mahanta ve Aggarwal (2013) tarafindan yapılan çalışmalarda kız öğrencilerin yaşam doyumunun erkek öğrencilerden anlamlı olarak daha yüksek olduğu görülmüştür. Gündoğar, Sallan-Gül, Uskun, Demirci ve Keçeci (2007) tarafından yapılan bir çalışmada ise üniversite öğrencilerinin yaşam doyumunu yordayan faktörlerin incelenmesi hedeflenmiş ve cinsiyetin yaşam doyumu üzerinde herhangi bir etkisi olmadığı bulgulanmıştır.

Pozitif psikolojide mutluluğun karşılığı olan “öznel iyi oluş" 'un en önemli unsuru olan yaşam doyumunun üniversite öğrencilerinin öğrenim hayatlarını büyük ölçüde etkilediği ve şekillendirdiği göz önünde bulundurularak yapılan bu çalışmada öncelikli olarak, üniversite öğrencilerinin yaşam doyumunun Namık Kemal Üniversitesi örneklemi üzerinden ölçülmesi hedeflenmektedir. Üniversite öğrencilerinin yaşam doyumlarında önemli rol oynayan sosyo-demografik değişkenlerin, toplumumuzu inşa edecek olacak genç neslin, yaşadığı dönemdeki mutluluk düzeylerini tespit etmede aydınlatıcı nitelikte olacağı düşünülmektedir. $\mathrm{Bu}$ nedenle ikincil amaç ise üniversite öğrencilerinin genel yaşam doyumu düzeylerini, cinsiyet, kalınan yer, ekonomik durum, fakülte, iş kaygısı, sosyal çevre ve sosyal etkinlik değişkenlerine göre incelemektir. Yapılan araştırma sonucunda elde edilen veriler doğrultusunda öğrencilerin yaşam doyumunu arttıracak etkinlikler yapılması beklenmekte ve çalışmamızın daha sonra yapılacak olan araştırmalara yol gösterici nitelikte olması hedeflenmektedir. 


\section{Yöntem}

\subsection{Evren ve Örneklem}

Araştırmanın örneklemi Namık Kemal Üniversitesi'nin çeşitli fakültelerinde öğrenim görmekte olan $390 \mathrm{kız}$ ve 385 erkek olmak üzere toplam 775 öğrenciden oluşmaktadır. Araştırmaya katılan öğrencilerin devam etmekte oldukları sinıflara bakıldığında 1.2. ve 3. sinıflara devam etmekte olan sirasiyla 215 (\%27.7), 249 (\%32.1) ve 163 (\%21) öğrencinin örneklemin çoğunluğunu oluşturduğu, bunun dışında 4 . sinıfa devam etmek olan 99 (\%12.8), 5. ve 6. sinıflara devam etmekte olan 45 (\%5.8) öğrenci olduğu görülmektedir. Araştırmaya dahil edilen 13 fakültedeki öğrenci dağılımları ise Tablo 1'de sunulmuştur.

Tablo 1. Fakültelere Göre Öğrenci Dağılımları

\begin{tabular}{lcc}
\hline Fakülteler & Öğrenci sayıs1 & $\%$ \\
\hline Fen-Edebiyat Fakültesi & 225 & 29 \\
Güzel Sanatlar Fakültesi & 50 & 6.5 \\
Veterinerlik & 14 & 1.8 \\
İktisadi ve İdari Bilimler Fakültesi & 90 & 11.6 \\
Ziraat Fakültesi & 89 & 11.5 \\
İlahiyat Fakülttesi & 35 & 4.5 \\
Mühendislik & 23 & 3 \\
Tip & 36 & 4.6 \\
Beden Eğitimi ve Spor MYO & 10 & 1.3 \\
Sosyal Bilimler MYO & 24 & 3.1 \\
Teknik Bilimler MYO & 65 & 8.4 \\
Sağlık Bilimleri MYO & 39 & 5 \\
Çorlu MYO & 75 & 9.7 \\
Toplam & 775 & 100 \\
\hline
\end{tabular}

\subsection{Veri Toplama Araçları}

\subsubsection{Kişisel Bilgi Formu}

Araştırmacılar tarafindan oluşturulan kişisel bilgi formunda öğrencilerin cinsiyeti, memleketleri, kaldıkları yer, aylık harcama miktarları, fakülte ve sinıfları, genel not ortalamaları, gelecekle ilgili iş bulma kaygıları, sosyal çevreleri ve etkinliklere katılma sıklklarıyla ilgili değerlendirmeleri, üniversiteyle ilgili eğitim beklentileri ve Tekirdağ'da yaşıyor olmakla ilgili memnuniyet düzeyleri sorulmuştur.

\subsubsection{Yaşam Doyumu Ölçeği}

Toplam 5 maddeden oluşan ve 7'li likert üzerinden değerlendirmelerin yapıldığı Yaşam Doyumu Ölçeği bireylerin genel yaşam doyumu düzeylerini ölçmek amaciyla Diener, Emmons, Larsen ve Griffin tarafindan 1985 y1lında geliştirilmiştir. Ölçekten alınabilecek toplam puanlar 7-35 arasında değişebilmektedir ve alınan puanların yükselmesi yaşam doyumunun yükseldiğine işaret etmektedir. Orijinal formunda madde toplam puan korelasyonlarının .57 ile .75 arasında olduğu ve test tekrar test korelasyon katsayısının .82 olduğu görülmektedir. Köker (1991) tarafından Türkçe'ye uyarlanmış olan Yaşam Doyumu Ölçeği'nin Türkçe formunun toplam puan korelasyonlarının yeterli olduğu bulunmuş test tekrar test güvenirlik katsayısı ise .85 olarak saptanmıştır.

\subsection{Verilerin Analizi}

$\mathrm{Bu}$ araştırma üniversite öğrencileri üzerinde yapılmış olup araştırmada yaşam doyumunun yordayıcılarıyla ilgili analizler yürütülmüştür. $\mathrm{Bu}$ amaçla Çoklu doğrusal regresyon analizi uygulanmıştır. Öncelikle kız ve erkek olmak üzere iki kategorili nominal değişken olarak ölçülmüş olan öğrenci cinsiyeti değişkeni dummy değişkene dönüştürülmüştür. Ayrıca analize sokulacak değişkenlerde kayıp veri olup olmadığına bakılmışır ve eksik olan veriler silinerek analize sokulmamıştır. Normal dağılım sınaması için Kolmogorov-Smirnov normal dağılım testi ile beraber basıklık ve çarpıklık değerlerinin incelenmesi planlanmıştır. Vaka sayılarının 100 ve üstünde olduğu ve/veya Kolmogorov-Smirnov test istatistiğinin anlamsız çıktı̆̆ ve/veya basıklık ve eğriklik değerlerinin \pm 3 ranjında seyrettiği durumlar için normal dağılım varsayımının karşılandığı kabul edilmiştir. Değişkenler arası ilişkileri test etmek amaciyla Pearson Korelasyon katsayıları kullanılmıştır. Yordayıcılar ve yordanan arasındaki doğrusal ilişki sınamaları ise nokta saçılım grafiği ve Fisher'ın Z testi ile gerçekleştirilmiştir. Çoklu doğrusallık ihlali olup olmadığ 1 ise tolerans ve varyans enflasyon faktörü ile değerlendirilmiş olup, 0.200-1 arasındaki tolerans değerleri ve 1-10 arasındaki VIF değerleri çoklu doğrusallı̆̆ın olmadığına kanıt olarak kabul edilmiştir. Çoklu doğrusal regresyon analizi için adımsal yöntem seçilmiştir. Tüm anlamlılık düzeyleri için $\mathrm{p}<.05$ değeri kullanılmıştır. Tüm analizler SPSS 22 versiyonunda yapılmıştır.

\section{Sonuç}

Doğrusal regresyon analizleri için tüm koşulların sınaması yapılmış ve tüm verilerin doğrusal regresyon analizi için uygunluğu gözlenmiştir. $\mathrm{Bu}$ aşamanın ardından öğrenci cinsiyetinin, kaldığı yerin, aylık harcama tutarının, fakülte ve bölümün, genel not ortalamasının, gelecekle ilgili iş bulma kaygısının, sosyal çevrenin, sosyal etkinliklere katılma sıklığının, eğitim beklentilerinin karşılanma düzeyinin ve Tekirdağ'da yaşamakla ilgili memnuniyetin genel yaşam doyumu üzerindeki yordayıcı etkisinin çoklu doğrusal adımsal regresyon analizi ile sınanması hedeflenmiştir. $\mathrm{Bu}$ amaçla her bir yordayıcının yordananla ve birbiriyle olan ilişkileri incelenmiş olup bu ilişkiler Ek 1'de sunulmuştur.

Ek 1'de de görüldüğü gibi yordayıc1 değişkenlerden cinsiyet, kalınan yer, aylık toplam gelir, fakülte, bölüm, sınıf, genel not ortalaması ve sosyal etkinliklere katılma sıklığı ile yaşam doyumu arasındaki ilişkilere dair Pearson korelasyon katsayıları .20'nin altında kaldığı için bu değişkenler regresyon analizine sokulmamıştır. Regresyon analizine, yordanan değişken olan ortalama yaşam doyumu skoruyla anlamlı korelasyon gösteren ve korelasyon katsayısı .20'nin üzerinde olan yordayıcı değişkenlerden iş kaygısı, Tekirdağ'da yaşıyor olma, kalınan yer, sosyal çevre ve üniversiteyle ilgili eğitim beklentileri sokulmuştur. Regresyon analizi bu değişkenlerden iş kaygısı, üniversitedeki eğitimin beklentileri karşılaması, sosyal çevre ve Tekirdağ'da yaşıyor olmanın yaşam doyumu puanındaki değişimin sırasıyla yaklaşık $\% 6, \% 3.4, \% 3.2$ ve $\% 1$ 'ini anlamlı düzeyde açıkladığını göstermiştir (sırasıyla, $\mathrm{F}_{(1,770)}=45.374, \quad p<.001 ; \quad \mathrm{F}_{(1,769)}=28.880, \quad p<.001 ;$ $\left.\mathrm{F}_{(1,768)}=27.934, p<.001 ; \mathrm{F}_{(1,767)}=8.725, p<.01\right)$. İlgili regresyon analiziyle ilgili bulgular Tablo 2 'de görülebilir. 
Tablo 2. Yaşam Doyumunun Yordayıcılarına Ilişkin Çoklu Doğrusal Adımsal Regresyon Analizi Sonuçları

\begin{tabular}{lcccccc}
\hline & $\Delta \mathrm{R}^{2}$ & $\mathrm{~B}^{*}$ & $\beta$ & $\mathrm{SE}$ & $\mathrm{t}$ & $p$ \\
\hline İş kaygısı & .056 & .550 & .199 & .094 & 5.831 & .000 \\
Eğitim beklentisi & .034 & .337 & .158 & .075 & 4.495 & .000 \\
Sosyal çevre & .032 & .414 & .170 & .083 & 5.016 & .000 \\
Tekirdağ'da yaşam & .010 & -.287 & -.104 & .097 & -2.954 & .003 \\
\hline
\end{tabular}

*Regresyon katsayıları 2. modelden alınmıştır.

\section{Tartıșma}

$\mathrm{Bu}$ çalışma sonucunda yaşam doyumu ile üniversitedeki eğitimin öğrencilerin beklentilerini karşılaması, iş kaygısı, sosyal çevre ve Tekirdağ'da yaşıyor olma değişkenleri arasında anlamlı ilişki saptanmıştır. Araştırmanın örneklemi göz önünde bulundurulduğunda ele aldığımız değişkenlerin yaşam doyumunu yorduyor olmasının çeşitli sebepleri üzerinde durulabilir. Bunlardan en önemlisi çalışmanın örneklemini üniversite öğrencilerinin oluşturmasıdır.

Yapılan çalışmada eğitim beklentisinin yaşam doyumunu yordayacağı yönündeki hipotezimiz desteklenmektedir. Örneklemimiz içerisinden üniversitede aldıkları eğitimden memnun olanların yaşam doyumu yüksekken, eğitim beklentisi karşılanamayanların yaşam doyumu düşük olmuştur. Bireylerin yaşam döngüleri incelendiğinde üniversite yıllarının geleceğe dair planların yapıldığı ve bu hedefleri gerçekleştirmek için gerekli alt yapının oluşturulmaya çalışıldığ y yllar olduğu gözlemlenmektedir. Üniversitede aldıkları eğitim bu bağlamda öğrencilerinin en çok önem verdiği unsurlar arasındadır. Gündoğar ve arkadaşlarının (2007) eğitimle ilgili doyumun öğrencilerin iyi olma halini etkileyen en önemli ikinci anlamlı yordayıcı olduğunu bulgulayan çalışması ve Cenkseven ve Akbaş'ın (2007) eğitim beklentisi karşılanan öğrencilerin bundan duyacakları hoşnutluk neticesinde olumlu duygular yaşayarak yüksek yaşam doyumuna sahip olacaklarını ifade ettikleri çalışması bulgularımızla paralellik göstermektedir. Kanada'da öğrencilerin akademik tatmini ile yaşam doyumu oranları arasında anlamlı ilişki tespit eden bir diğer araştırma ise bulgularımızın farklı kültürlerle de aynı çizgide olduğunu gözler önüne sermektedir (Chow, 2005).

Yaşam doyumunun yordayıcısı olan bir diğer değişken ise iş kaygısıdır. Diğer değişkenlerde olduğu gibi, iş kaygısına dair sonuçta da örneklem grubunun üniversite öğrencileri arasından seçilmiş olması faktörü öne çıkmaktadır. Yapılan çalışmalar yaşam doyumunun sahip olunan işle ya da iş beklentisiyle yakından ilişkili olduğunu göstermektedir (Gündoğar ve ark., 2007). İş sahibi olanların yaşam doyumu yüksek olurken, işsiz olanların ve bu kaygı içerisindeki kişilerin yaşam doyumlarının büyük oranda düşük olduğu tespit edilmiştir (Strand, 2000). Benzer şekilde Sağlık Yönetimi öğrencilerinin yaşam doyumunu mercek altına alan bir araştırmada öğrencilerin yaşam doyumunu en fazla etkileyen değişkenin işsizlik kaygısı olduğu sonucuna ulaşılmış, öğrencilerin işsizlik kaygıları arttıkça yaşam doyumlarının azaldığı bulgulanmıştır (Turaç ve Bayın, 2017). Ayrıca farklı bir çalışmada da üniversite öğrencilerinin \%96'sının ekonomik bağımsızlığa önem verdiklerini gösterilmektedir (Özkul, 2007). Bu araştırmalardan ortaya çıkan sonuçlar da göz önünde bulundurulursa üniversite eğitiminin bireylerin iş hayatına atılmadan önceki son basamakları olduğunu varsaydığımızda, bu grubun yaşam doyumu oranı ile iş yaşamına dair kaygıları arasındaki anlamlı ilişki açıklığa kavuşmaktadır.

Stukalina (2014), üniversitenin, öğrencilerin kişilik gelişimlerinin yanı sıra sosyalleşmelerine de katkıda bulunan sosyal bir alan olduğunu ifade etmektedir. Dolayısıyla üniversite öğrencilerinde yalnızlık yani sosyal ilişki ağındaki eksiklik duygusu ya da sosyal çevrenin varlığ 1 yaşam doyumunun önemli belirleyicilerindendir (Kapıkıran, 2012; Tuzgöl-Dost, 2007; Cenkseven ve Akbaş, 2007). Çalışmamızın bulguları da bu bilgilerle paralellik göstermekte ve sosyal çevre ile yaşam doyumu arasındaki ilişkiyi bir kez daha gözler önüne sermektedir. Özellikle üniversite öğrencilerinin birçoğunun ailesinden uzakta geçirdikleri yeni bir çevreye ve ilişkilere uyum sağlama süreçlerini düşünecek olursak, sosyal çevrenin yani olumlu arkadaşlık ilişkilerine sahip olmanın yaşam doyumuyla ilişkili olması daha da anlam kazanmaktadır. Arkadaşlarla birlikte olmak bireyin hem sosyal hem de psikolojik ihtiyaçlarını karşılamaktadır (Cenkseven ve Akbaş, 2007).

Yapılan çalışmanın bulgularına göre, örneklemin yaşam doyumunu yordayan bir diğer değişkeni de Tekirdağ'da yaşıyor olma durumudur. Çalışma kapsamına alınan öğrencilerin gündelik yaşamlarında öne çıkan bir faktör olan yaşanılan il noktasına dair bir dizi çıkarım yapmak mümkündür. 2012 yılında Büyükşehir statüsü kazanmış olan Tekirdağ'ın dışarıdan gelen öğrenciler tarafından en çok eleştirilen yönü sosyal mekan ve aktivite yetersizliğidir. Her ne kadar artan öğrenci sayısına paralel olarak öğrencilerin barınma ve sosyalleşme mekan ve imkanlarında bir artış gözlemlense de ögrencilerin gözünde bunların yeterli sayı ve kapsamda olmadığı bilinmektedir. Çalışma sonuçlarımızdan mekan ve sosyal yaşama dair elde edilen bulgular bu noktayı daha da belirginleştirmektedir. Öğrencilerin yaşam doyumu oranlarında Tekirdağ ilinde yaşıyor olmak ve sosyal yaşam değişkenlerinin anlamlı etkisi şehrin bu yönünden kaynaklanıyor olabilir. Literatürün aksine (Çalışkan, Yasul ve Ulaş, 2017, Aytekin ve Tunalı, 2017; Sungur, 2016; Güllüoğlu Işık ve Koçak, 2014), maddi durumun yaşam doyumunu yordayan değişkenler arasında yer almaması Tekirdağ ilinin dışarıda vakit geçirme olanaklarının kısıtlılığıyla açıklanabilir. Diğer bir ifadeyle, öğrencilerin harcama yapacakları mekan ya da organizasyonların çok fazla olmaması, aylık harcama tutarlarının yaşam doyum oranları üzerinde anlamlı bir etkiye sahip olmamasına neden olabilir.

Cinsiyet ve yaşam doyumu arasında ilişki olup olmadığıyla ilgili literatürde çelişkili sonuçlarla karşılaşılmaktadır. $\mathrm{Bu}$ çalışmanın sonuçları ise, yaşam doyumunu belirlemede cinsiyetin etkili olduğunu bulgulayan çalışmaları değil (Tuzgöl Dost, 2007; Mahanta ve bu cinsiyetin yaşam doyumuna anlamlı bir etkisini bulamayan çalışmalarla (örn., Weinstein ve Laverghetta, 2009; Gündoğar ve ark., 2007) paralellik göstermektedir.

Çalışmada kullanılan örneklemin genişliği bu çalışmanın güçlü yanlarındandır. Ayrıca küçük şehirlerdeki üniversite yaşamında karşılaşılabilecek olan faktörleri gözler önüne sermesi bakımından da değerli bir çalışmadır. Ancak bu çalışmanın sonuçları değerlendirilirken araştırmanın sınırlılıkları da göz önünde bulundurulmalıdır. Öğrencilerin yaşam doyumunu büyük ölçüde etkileyebilecek demografik ve psiko-sosyal bir çok faktör çalışmaya dahil edilmemiştir. Gelecek çalışmalar, öğrencilerin sağlık durumları, duygusal 
ilişkileri ve aile ilişkileri de göz önünde bulundurularak genişletilebilir. Ayrıca değişkenlerin ayrıntıya girilmeden evet/ hayır ya da likert derecelendirmeyle alınması ve ölçümlerin katılımcıların kendilerini rapor etmelerine dayanması çalışmanın sınırlılıklarındandır. Bu kapsamda gelecek çalışmalarda odak grup yöntemi kullanılarak, elde edilen niteliksel veriler niceliksel verileri açıklamak için kullanılabilir.

Özetle, bu araştırma kapsamında Tekirdağ Namık Kemal Üniversitesi öğrencilerinin yaşam doyumlarını yordayan değişkenlerin saptanması amaçlanmıştır. Farklı fakülte ve sınıflarda öğrenim gören yedi yüz yetmiş beş öğrencinin katılımıyla gerçekleştirilen çalışmada, iş kaygısı, eğitim beklentisi, sosyal çevre ve Tekirdağ'da yaşam faktörlerinin yaşam doyum oranlarını anlamlı olarak yordayan değişkenler olduğu görülmüştür. Bu kapsamda Tekirdağ Namık Kemal Üniversitesi öğrencilerinin iş kaygılarının hafifletilerek yaşam doyumlarının artırılması için iş alternatifleriyle ilgili seminerler düzenlenmesinin ve öğrencilerin üniversite bünyesindeki Kariyer ve Uygulama Merkezine daha sık yönlendirilmesinin etkili olabileceği düşünülmüştür. Ayrıca sonuçlardan yola çıkarak sosyal etkinliklerin çoğaltılması ve öğrenci kulüplerinin desteklenmesi, psikolojik destek birimlerinin oluşturulması ve öğrencilere Tekirdağ'da yaşam, sosyal beceri kazanımı, kendini geliştirme ve yaşam doyumu gibi konularda verilen seminerlerin daha çok öğrenciye ulaşabilmek adına artırılması önerilmektedir.

\section{Kaynakça}

Akın, A., Arslan S., Çelik, E., Kaya, Ç., \& Arslan, N. (2015). Student Academic Support as a Predictor of Life Satisfaction in University Students. Eurasian Academy of Sciences Journal, 2, 38-49.

Aytekin, A., \& Tunalı, D. (2017). ÖYP Araştırma Görevlilerinin Yaşam Doyumlarının İkili Lojistik Regresyon Analizi ile İncelenmesi. Uluslararası Yönetim Iktisat ve Işletme Dergisi, 13 (1), 247-270.

Cenkseven, F., \& Akbaş, T. (2007). Üniversite Öğrencilerinde Öznel ve Psikolojik İyi Olmanın Yordayıcılarının İncelenmesi. Türk Psikolojik Danışma ve Rehberlik Dergisi, 3 (27), 43-65.

Chow, H.P.H. (2005). Life Satisfaction Among University Students in a Canadian Praire City: a Multivariate Analysis. Social Indicactors Research, 70, 139-150.

Çalışkan, E.F., Yasul, A.F., \& Ulaş, A.H., (2017). Öğretmen Adaylarının Sosyal Değer Algıları ile Yaşam Doyumları Arasındaki İlişkinin İncelenmesi. Education Sciences (NWSAES), 12(3), 133-146.

Çivitçi, A. (2012). Üniversite Öğrencilerinde Genel Yaşam Doyumu ve Psikolojik İhtiyaçlar Arasındaki İlişkiler. Ç.Ü. Sosyal Bilimler Enstitüsü Dergisi, 21(2), 321-336.

Diener, E. (2000). Subjective Well-Being: The Science of Happiness and a Proposal for a National Index. American Psychologist, 55(1), 34-43.

Diener, E., Emmons, R. A., Larsen, R. J., \& Griffin, S. (1985). The Satisfaction with Life Scale. Journal of Personality Assessment, 49, 71-75.
Diener, E., Suh, E., Lucas, R.E., \& Smith, H.E. (1999). Subjective Well-Being: Three Decades of Progress. Psychological Bulletin, 125(2), 276-302.

Eid, M., \& Diener, E. (2004). Global Judgments of Subjective Well-Being: Situational Variability and LongTerm Stability. Social Indicators Research, 65, 245-277.

Ergin, A., Hatipoğlu, C., Bozkurt, A.İ., Bostanc1, M., Atak B.M., Kısaoğlu, S., Parasız, S., Kaygısız H., Çınarlık, A., \& Karasu, E., (2011). Tip Fakültesi Öğrencilerinin Yaşam Doyumu ve Özbakım Gücü Düzeyleri ve Etkileyen Faktörler. Pamukkale Tıp Dergisi, 4(3), 144151.

Gündoğar, D., Gül, S.S., Uskun, E., Demirci, S., \& Keçeci, D. (2007). Üniversite Öğrencilerinde Yaşam Doyumunu Yordayan Etkenlerin İncelenmesi. Klinik Psikiyatri Dergisi, 10, 14-27.

Huang, C.Y. (2003). The relationships among leisure participation, leisure satisfaction, and life satisfaction of college students in Taiwan. Doktora Tezi. Texas: University of Incarnate Word.

Keyes, C.L., Shmotkin, D., \& Ryff, C. (2002). Optimizing Well-Being: The Emprical Encounter of Two Traditions. Journal of Personality and Social Psychology, 82, 1007 1022.

Mahanta, D., \& Aggarwal, M. (2013). Effect of Perceived Social Support on Life Satisfaction of University Students. European Academic Research, 1(6).

Martin Sigmund, M., Kvintová, J., Hřebíčková, H., Šafář M., \& Sigmundová, D. (2014). Life Satisfaction, Health, Self-Evaluation and Sexuality in Current University Students of Sport Sciences, Education and Natural Sciences. Acta Gymnica, 44(4), 2014, 231-241.

Matheny, K. B., Curlette, W. L., Aysan, F., Herrington, A., Gfroerer, A., Thompson, D., \& Hamarat, E. (2002). Coping Resources, Perceived Stress, and Life Satisfaction Among Turkish and American University Students. International Journal of Stress Management, 9(2).

Ozben, S. (2013). Social Skills, Life Satisfaction and Loneliness in Turkish University Students. Social Behavior and Personality: An International Journal, 41 (2), 203-213.

Özaydın, N., Sevinç, S., \& Deniz, M.E. (2014). Mesleki Müzik Eğitimi Alan Öğrencilerin Psikolojik İhtiyaçlarının ve Yaşam Doyumlarının İncelenmesi. Sanat Eğitimi Dergisi, 2(1).

Özgür, G., Gümüş, A. B., \& Durdu, B. (2010). Evde ve Yurtta Kalan Üniversite Öğrencilerinde Yaşam Doyumu, Psikiyatri Hemşireliği Dergisi, 1, 25-38.

Özkul, A.S. (2007). Yaşam ve çalışma değerlerini etkileyen faktörler. Sdü ögrencileri üzerine bir araştırma. Yüksek Lisans Tezi. Isparta: Süleyman Demirel Üniversitesi.

Pavot, W., \& Diener, E. (1993). Review of the Satisfaction with Life Scale. Psychological Assessment, 5(2), 164172. 
Seligman, M.E.P., \& Csikszentmihalyi, M. (2000). Positive Psychology: An Introduction. American Psychologist, 55, 5-14.

Strandh, M. (2000). Different Exit Routes from Unemployment and Their Impact on Mental Wellbeing: The Role of Economic Situation and Predictability of the Life Course. Work, Employment and Society, 14 (3), 459479.

Sungur, M.A. (2016). Düzce Üniversitesinde Yükseköğrenim Gören Yabancı Uyruklu Öğrencilerin Yaşam Doyumları ve Sosyal Uyumlarını Etkileyen Faktörler, Düzce Üniversitesi Sağllk Bilimleri Enstitüsü Dergisi, 6(2), 101-109.

Turaç, İ.S., \& Bayın, G. (2017). Sağlık Yönetimi Öğrencilerinin İşsizlik Kaygılarını ve Yaşam Doyumlarını Etkileyen Faktörlerin Belirlenmesi. ICPESS 2017-Sarajevo, Bosnia Herzegovina.

Tuzgöl Dost, M. (2007). Üniversite Öğrencilerinin Yaşam Doyumunun Bazı Değişkenlere Göre İncelenmesi. Pamukkale Üniversitesi Ĕ̌itim Fakültesi Dergisi, 22, 132-143.

Weinstein, L., \& Laverghetta, A. (2009). College Student Stress and Satisfaction with Life. College Student Journal, 43(4), 1161-1162.

\section{Ekler}

Ek 1. Yordayıcılar ve Yordanan Arasındaki Ilişkilere Dair Pearson Korelasyon Katsayıları

\begin{tabular}{|c|c|c|c|c|c|c|c|c|c|c|c|c|c|}
\hline & $\mathrm{YD}^{1}$ & Cinsiyet & $\begin{array}{c}\text { İş } \\
\text { kaygıs1 }\end{array}$ & Tekirdağ & $\begin{array}{c}\text { Kalınan } \\
\text { yer }\end{array}$ & Harcama & Fakülte & Bölüm & Sinif & GPA & $\begin{array}{c}\text { Sosyal } \\
\text { çevre }\end{array}$ & Etkinlik & $\begin{array}{c}\text { Eğitim } \\
\text { beklentisi }\end{array}$ \\
\hline $\mathrm{YD}^{1}$ & 1 & -.042 & $.237 * * *$ & $-.158 * * *$ & $.078 *$ & .048 & .069 & .048 & -.004 & -.010 & $.202 * * *$ & $.101 * *$ & $.210 * * *$ \\
\hline Cinsiyet & & 1 & $.117 * *$ & .038 & $.196 * * *$ & $.237 * * *$ & $.199 * * *$ & $.203 * * *$ & .036 & $\begin{array}{c}- \\
.204^{* * *}\end{array}$ & -.041 & $-.089 *$ & -.029 \\
\hline İş kaygısı & & & 1 & .003 & $.097 *$ & $.153^{* * * *}$ & $.225 * * *$ & .198 & -.047 & .016 & $.100^{* *}$ & -.027 & $.123 * * *$ \\
\hline Tekirdağ & & & & 1 & -.043 & .038 & -.054 & -.053 & .007 & -.009 & $-.088^{*}$ & $-.124 * *$ & $-.268 * * *$ \\
\hline Kalınan yer & & & & & 1 & $.275^{* * * *}$ & $.140 * * *$ & $.110^{* *}$ & $.236^{* * *}$ & $\overline{-}^{-} .137^{* * *}$ & .040 & $-.135^{* * *}$ & .054 \\
\hline Harcama & & & & & & 1 & $.078 *$ & $.103 * *$ & $.304 * * *$ & -.064 & $.104 * *$ & -.068 & -.030 \\
\hline Fakülte & & & & & & & 1 & $.758 * * *$ & -.008 & .051 & -.014 & -.047 & -.056 \\
\hline Bölüm & & & & & & & & 1 & $-.094 * *$ & .005 & -.040 & -.053 & -.013 \\
\hline Sinif & & & & & & & & & 1 & $-.081 *$ & $.097 * *$ & .019 & $-.138 * * *$ \\
\hline GPA & & & & & & & & & & 1 & .052 & $.095 * *$ & .003 \\
\hline $\begin{array}{l}\text { Sosyal } \\
\text { çevre }\end{array}$ & & & & & & & & & & & 1 & $.213 * * *$ & .008 \\
\hline Etkinlik & & & & & & & & & & & & 1 & $.076^{*}$ \\
\hline $\begin{array}{l}\text { Eğitim } \\
\text { beklenti }\end{array}$ & & & & & & & & & & & & & 1 \\
\hline
\end{tabular}

